\title{
Geographical analysis of six rare bird species in the Kruger National Park, South Africa
}

\author{
J. L. HURFORD, A. T. LOMBARD, A. C. KEMP and G. A. BENN
}

\begin{abstract}
Summary
Twenty-eight predominantly tropical bird species have ranges that only just extend into the north-eastern part of South Africa, mainly within the Kruger National Park (KNP). These species are listed as "rare" (<200 breeding pairs) in the South African Red Data Book (Brooke 1984). This study assesses the extent to which six of these rare bird species represent viable populations in the KNP. Grid squares in the KNP $(2.5 \times 2.5$ miles $)$ were visually assessed according to several bird habitat parameters. Bird records were also plotted on this grid system and habitat associations were identified for each species. This allowed for the measurement of total suitable habitat within the KNP for each species. Bird densities within known habitat were determined using spot-mapping and fixed-distance strip-transect techniques. Estimated population sizes for each species were obtained by extrapolating density estimates to total suitable habitat. Of the six study species, Arnot's Chat, Rudd's Apalis, Wattle-eyed Flycatcher and Tropical Boubou are likely to occur in sufficient numbers to constitute viable populations within the KNP, with estimated population sizes of $1,394,4,758,2,070$ and 10,450 birds respectively. The populations of White-crowned Plover and Long-tailed Starling are probably too small to be viable in the long term, with estimated population sizes of 305 and 382 birds respectively. The results presented here are testable and can be used as a baseline for future monitoring.
\end{abstract}

\section{Introduction}

The Kruger National Park (KNP), situated in the north-eastern corner of South Africa (Figure 1 ), is the largest conserved region in the country and covers an area of approximately $20,000 \mathrm{~km}^{2}$. Over $50 \%$ of the bird species in the South African Red Data Book (Brooke 1984) are reported to occur in the KNP. Some species are particularly dependent on the park for their existence as breeding species in South Africa. This highlights the importance of the KNP for the conservation of the country's rich avian biodiversity.

In recognition of the importance of the KNP for bird conservation in South Africa, a project was initiated to determine the viability of rare birds in the park. Two types of avian rarity are recognized in the KNP: (i) very large birds which have extensive spatial requirements and exist naturally at low densities; and (ii) small bird species that are rare simply because their ranges only just extend into the KNP, where their habitat is limited. The research reported here focuses on the latter. Within South Africa these small species occur mainly within the 


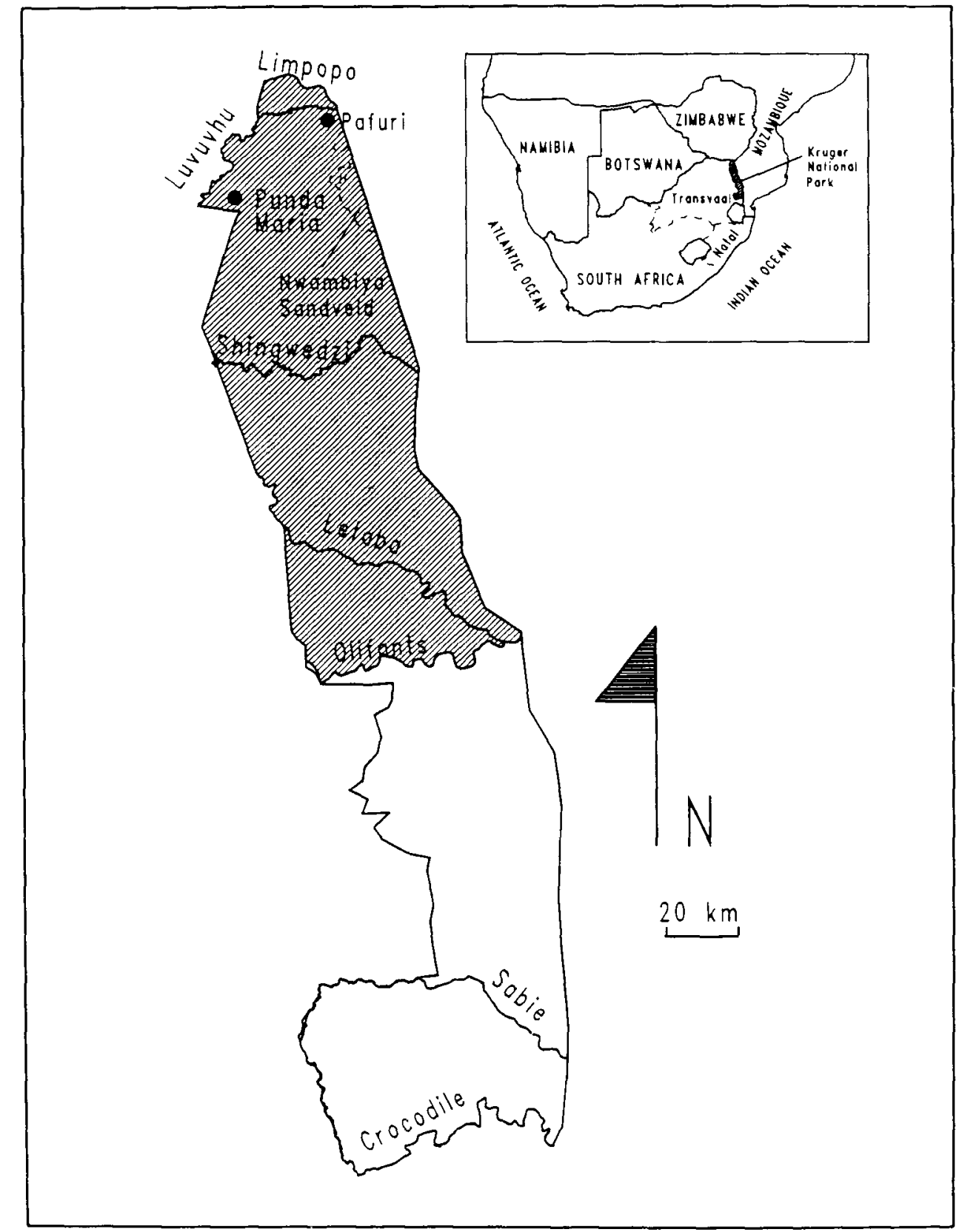

Figure 1. The KNP showing the study area (shaded region), major rivers and areas referred to in the text. The inset is a map of southern Africa indicating the position of the KNP, as well as the Transvaal and Natal provinces within South Africa. 
Table 1. List of rare peripheral species reported to occur within the KNP.

\begin{tabular}{|c|c|c|}
\hline & Common name & Scientific name \\
\hline Category 1 & $\begin{array}{l}\text { Dwarf Bittern } \\
\text { Bat Hawk } \\
\text { Three-banded Courser } \\
\text { Red-winged Pratincole } \\
\text { Thick-billed Cuckoo } \\
\text { Black Coucal } \\
\text { Pennant-winged Nightjar } \\
\text { Racket-tailed Roller } \\
\text { Mosque Swallow } \\
\text { White-breasted Cuckoo-shrike } \\
\text { Mashona Hyliota } \\
\text { Yellow White-eye } \\
\text { Pink-throated Twinspot } \\
\text { Lemon-breasted Canary }\end{array}$ & $\begin{array}{l}\text { Ixobrychus sturmii } \\
\text { Macheiramphus alcinus } \\
\text { Rhinoptilus cinctus } \\
\text { Glareola pratincola } \\
\text { Pachycoccyx audeberti } \\
\text { Centropus bengalensis } \\
\text { Macrodipteryx vexillaria } \\
\text { Coracias spatulata } \\
\text { Hirundo senegalensis } \\
\text { Coracina pectoralis } \\
\text { Hyliota australis } \\
\text { Zosterops senegalensis } \\
\text { Hypargos margaritatus } \\
\text { Serinus citrinipectus }\end{array}$ \\
\hline Category 2 & $\begin{array}{l}\text { Dark Chanting Goshawk } \\
\text { Dickinson's Kestrel } \\
\text { Crested Guineafowl } \\
\text { Mourning Dove } \\
\text { Cape Parrot } \\
\text { Mottled Spinetail } \\
\text { Boehm's Spinetail } \\
\text { Yellow-billed Oxpecker }\end{array}$ & $\begin{array}{l}\text { Melierax metabates } \\
\text { Falco dickinsoni } \\
\text { Guttera pucherani } \\
\text { Streptopelia decipiens } \\
\text { Poicephalus robustus suahelicus } \\
\text { Telacanthura ussheri } \\
\text { Neafrapus boehmi } \\
\text { Buphagus africanus }\end{array}$ \\
\hline Category 3 & $\begin{array}{l}\text { White-crowned Plover } \\
\text { Arnot's Chat } \\
\text { Rudd's Apalis } \\
\text { Wattle-eyed Flycatcher } \\
\text { Tropical Boubou } \\
\text { Long-tailed Starling }\end{array}$ & $\begin{array}{l}\text { Vanellus albiceps } \\
\text { Thamnolaea arnoti } \\
\text { Apalis ruddi } \\
\text { Platysteira peltata } \\
\text { Laniarius aethiopicus } \\
\text { Lamprotornis mevesii }\end{array}$ \\
\hline
\end{tabular}

These species can be divided into three groups: small, eruptive species (category 1); small species with patchy habitat requirements (category 2); small species with specific and limited habitat requirements (category 3).

KNP (Kemp 1980) so that their maintenance in South Africa depends largely on the KNP. The South African Red Data Book for birds (Brooke 1984) lists 28 species that have rare ( $<200$ breeding pairs), peripheral populations within the KNP and South Africa (Table 1). During our field study, it became apparent that these species could be further divided into three categories (Table 1): small, eruptive species that expand their ranges into the KNP only under certain conditions (category 1), small species with specific and patchy habitat requirements (category 2), and small species which require specific and contiguous limited habitat (category 3). The group of eruptive species (category 1) was found to be non-resident or too scarce to study. These species can be regarded as "spillovers" (Pulliam 1988, Stevens 1992) from a more productive neighbouring source and do not have viable populations in the KNP. Research on the viability of those species with specific and patchy habitat requirements (category 2) is still ongoing. This study evaluates the viability of species with specific and contiguous limited habitat (category 3). This necessitates (i) documenting the ranges of the study species within the KNP, (ii) identifying their habitat associations, (iii) assessing the availability of suitable habitat in the 
KNP for each species, and (iv) determining their densities in suitable habitats and thus estimating their total numbers. It is intended that these data will serve as a baseline against which future populations can be monitored and conservation management planned.

\section{Methods}

\section{Study area}

Since the small rare species are mostly confined to the northern KNP, the study area comprised the KNP north of the Olifants River, an area of approximately $10,545 \mathrm{~km}^{2}$ (Figure 1). The area is drained by three major river systems: the Olifants/Letaba, the Shingwedzi and the Limpopo/Luvuvhu. This area receives on average between 450 and $600 \mathrm{~mm}$ of rain a year, most of which falls between September and March (Gertenbach 1980). During the study period, however, the KNP suffered extreme drought with a 1991/92 summer rainfall as low as $52 \mathrm{~mm}$ recorded in the Pafuri region.

\section{Data collection and analyses}

Data were collected continuously over the two-year study period, from January 1991 to January 1993. Data were mapped according to the conventional grid system of $2.5 \times 2.5$ miles $(\sim 4 \times 4 \mathrm{~km})$ used by the National Parks Board for the KNP. The grid squares are further divided into quarters of $1.25 \times 1.25$ miles each $(\sim 2 \times 2 \mathrm{~km})$. The analyses for this study were completed using a Geographic Information System (GIS, ARC/INFO, version 3.4D+, Environmental Systems Research Institute, Redlands, California). Data layers of the KNP boundary, roads, rivers and camps were digitized off 1:50,000 topographical maps (Chief Directorate of Surveys and Land Information, South Africa).

\section{Documenting species' ranges within the KNP}

During the study period, an attempt was made to survey the entire study area, by vehicle or on foot, and record all sightings of study species on the $2 \times 2 \mathrm{~km}$ grid. Additional information such as sex, age, nesting and immediate habitat was also recorded for each sighting where possible. The minimum geographic ranges of each study species were thus determined by plotting sightings of each species. This ensured that density estimates were not extrapolated to areas outside the known ranges of each species. Breeding and non-breeding distributions for the six study species are considered to be the same since they are described as sedentary (Maclean 1993).

\section{Identifying species-habitat associations}

Species-habitat assessments, encompassing a radius of $400 \mathrm{~m}\left(0.5 \mathrm{~km}^{2}\right)$, were conducted for every study species sighting. The habitat parameters assessed included presence of water features, percentage open canopy, extent of ground 
cover, and percentage woody vegetation (percentage tree, bush and scrub cover occupied by Combretum spp., Terminalia spp., Mopane spp., Acacia spp. and the riparian belt were specifically recorded). These habitat assessments, together with an a priori knowledge of each species's habitat preferences, were used as an aid to selecting habitat parameters important for each species. Only those habitat parameters considered important for each species were included in the search criteria used to extract available suitable habitat for each species.

\section{Assessing availability of suitable habitat for each species}

The extent of suitable habitat for each species was determined by visually assessing and mapping habitat parameters at the $4 \times 4 \mathrm{~km}\left(16 \mathrm{~km}^{2}\right)$ grid scale. The habitat parameters assessed were the same as those in the species-habitat assessments. In order to identify all suitable habitat for a species, habitat assessments for grid squares $\left(16 \mathrm{~km}^{2}\right)$ where that particular species was sighted during the study period were extracted from the database and frequency distributions of each habitat parameter considered important for that species were generated. These frequency distributions were then used to define search criteria. For example, if \% tree cover is taken as being important for a particular species and the species has only been recorded in grid squares where $\%$ treecover $>20 \%$, then the search criterion for that species would be $\%$ tree cover $>20 \%$. Using the search criteria (e.g. tree cover $>20 \%$ ), all other grid squares qualifying as suitable within the range of each species were identified. Area of suitable habitat within a grid square was then calculated as the proportion of the grid square area occupied by the habitat parameter (e.g. tree cover) considered important for each species. For example, if tree cover is important for a species and within a particular grid square $\%$ tree cover $=30 \%$, then the area of suitable habitat within that grid square was assumed to be $30 \%$ of the grid square area.

\section{Density and population size estimation}

For each species, number of birds within a specified transect area were calculated. Methods of censusing differed among species (Table 2). Observer bias (Verner 1985) was minimal because transects were conducted by the same observers (P. Chadwick, K. Begg, G. Benn), who were familiar with the study species. Bias resulting from differences in bird detectability was taken into account and width of transect was adjusted accordingly (Bibby et al. 1992). Differences in diurnal activity were recognized as a source of bias and transects were conducted only in the early morning or late afternoon to minimize diurnal bias (Verner 1985). Furthermore, search effort for each species was standardized and transects were not conducted in extreme weather conditions.

In order to estimate population sizes, bird densities were calculated using the transect techniques detailed in Table 2. Densities were then extrapolated to the total area of suitable habitat for each species. Two different methods were used to obtain density estimates from transect data:

(i) The spot-mapping method was employed to estimate the density of all species except the Long-tailed Starling. Spot-mapping is a procedure that plots, 


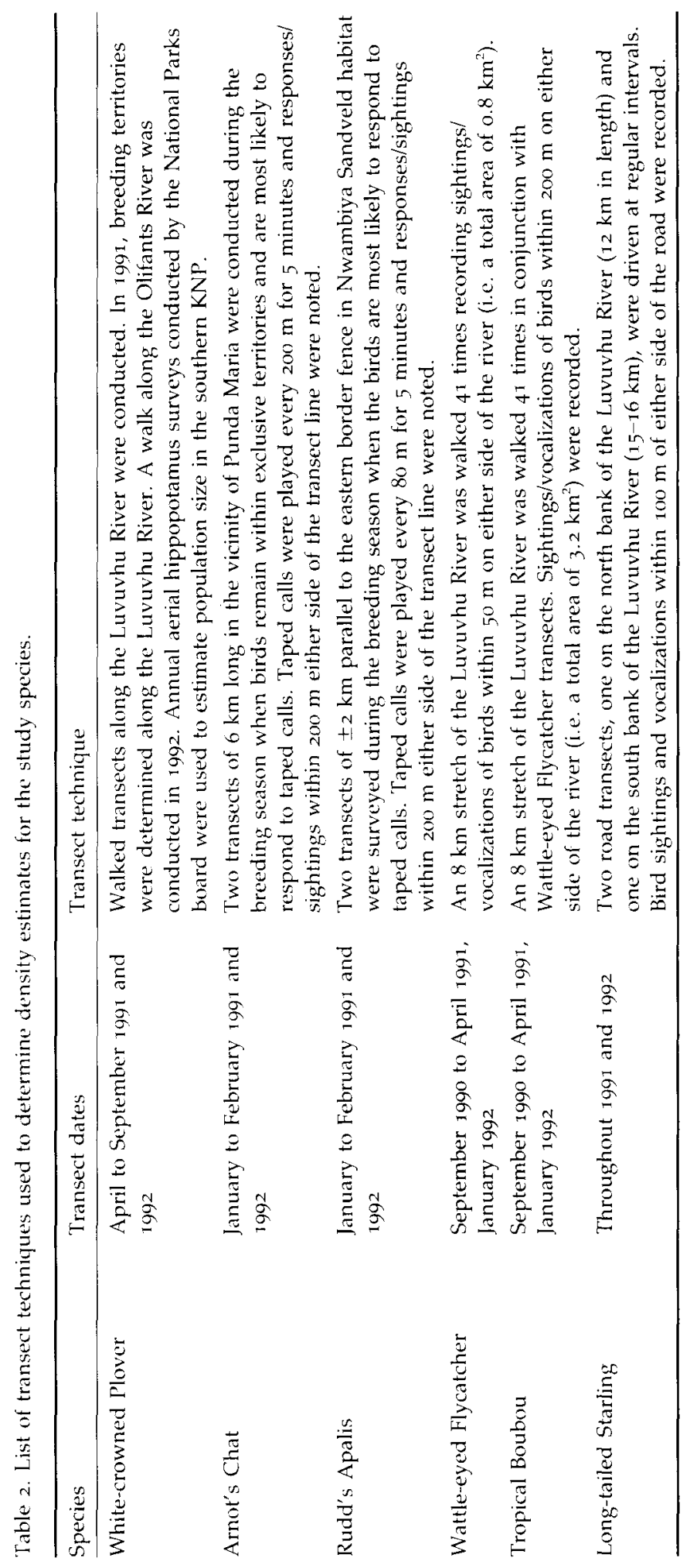


on a map, cumulative number of bird territories after several visits to the area. "Clusters" of locations are identified and assumed to represent centres of activity by territory holders (Edwards et al. 1981, Franzreb 1981, Verner 1985). This method is appropriate for estimating densities of cryptic bird species since the area is visited several times, thus providing opportunity to discover all, or most, territories in the area. However, the method is fairly inflexible in that it is usually restricted to certain times of year when the birds are breeding and therefore remain within confined territories. Moreover, no margin of error can be placed on the density estimate derived (Bibby et al. 1992).

(ii) The fixed-distance strip-transect method was employed to estimate density of the non-territorial Long-tailed Starling. This involves counting all birds within a fixed width of a strip of land and dividing this number by the area of the transect to obtain density (Verner 1985). This method differs from spot-mapping in that densities are calculated from mean number of birds, instead of cumulative number of birds, per transect. Since mean density is calculated from replicate samples, a margin of error can be placed on the density estimate derived. This method of density estimation is best for conspicuous and/or vocal species, since it relies on the assumption that all birds present within the transect area are detected. However, densities of the smaller, more cryptic bird species tend to be underestimated, because it is unlikely that all individuals within the transect area are detected per transect.

For cryptic species, the spot-mapping method of estimating density is preferable even though no margin of error can be placed on the estimate. Spot-mapping also provides a useful index with which to calibrate future, more flexible fixed-distance strip-transects. By comparing the total number of territories discovered by spot-mapping (e.g. 100) with the mean number of territories discovered per transect (e.g. 5o), a calibration factor (in this case $50 \%$ ) can be derived with which to calibrate future fixed-distance strip-transects.

\section{Results}

\section{Measurement of available suitable habitat and the importance of scale}

The habitat assessments within a $400 \mathrm{~m}$ radius of a species $\left(0.5 \mathrm{~km}^{2}\right)$ gave an indication as to which habitat parameters were important for each bird species. They also drew attention to a scale-related problem in the measurement of extent of suitable habitat for some species. The resolution of the grid square habitat assessments $\left(16 \mathrm{~km}^{2}\right)$ greatly exceeds the potential territory size of all study species. At the coarser $4 \times 4 \mathrm{~km}$ scale, habitat is relatively homogeneous (neighbouring grid squares are similar), but within the grid square at a scale relevant to the study species the habitat was found to be heterogeneous. Measuring the extent of suitable habitat using the grid square habitat assessments will, therefore, not produce accurate results. Scale problems such as these are prevalent in studies which predict species distributions based on habitat distributions and preferences (Turner et al. 1989, Stoms 1992, 1994) where trade-offs exist between mapping effort and habitat detail. The scale-related problem in this study can be illustrated by the following example. The Long-tailed Starling is found in $4 \times 4 \mathrm{~km}$ grid squares where bare ground 
(a) Grid square assessment

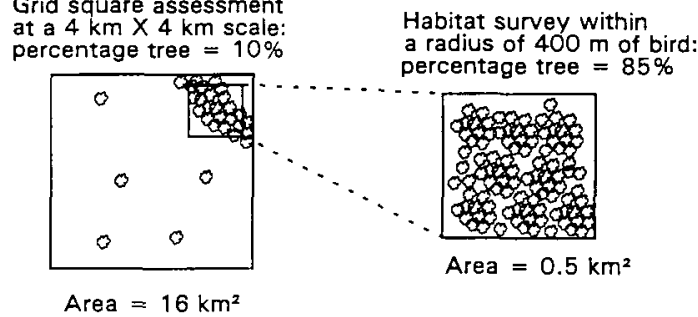

(b)

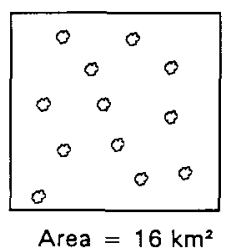

Figure 2. (a) Schematic representation of habitat heterogeneity within a $4 \times_{4} \mathrm{~km}$ grid square. (b) $\mathrm{A}_{4} \times{ }_{4} \mathrm{~km}$ grid square in which trees are present in the same proportion as (a), but are dispersed differently. For a bird seeking dense woodland, only the dense tree habitat in (a) is suitable.

is $>50 \%$ and $\%$ tree cover $>10 \%$. The $\%$ tree cover is surprisingly low, considering that habitat assessments within a $400 \mathrm{~m}$ radius of a bird sighting document this species in areas where \% tree cover is most often between 30 and $40 \%$. This problem arises because of differences in scale (Figure 2a). It is clear from Figure $2 a$ that extrapolating Long-tailed Starling density to the entire area of the grid square $\left(16 \mathrm{~km}^{2}\right)$ would grossly overestimate population size, since suitable tree habitat for Long-tailed Starlings occurs only in $0.5 \mathrm{~km}^{2}$ of the area. This problem was resolved by measuring suitable habitat for a species as the percentage of grid square area occupied by the habitat parameter deemed important for that species, rather than using the entire grid square area. Nevertheless, distribution of habitat within the grid square is also important and less easily resolved. Figure $2 b$ shows a grid square in which trees are present in the same proportion as in Figure 2a, but are distributed differently. There is a patch of potentially suitable habitat for Long-tailed Starlings in Figure 2a. However, the distribution of trees is so scattered in Figure $2 \mathrm{~b}$ that none of the habitat can be regarded as suitable for this species.

Extrapolating density estimates across these widely differing scales is not serious for the riparian study species, for example the Wattle-eyed Flycatcher and Tropical Boubou, because the riparian belt within a grid square is clumped. The problem of scale is more applicable to species whose habitat is scattered within the grid square, for example, Arnot's Chat, Rudd's Apalis and Long-tailed Starling.

\section{Population sizes}

White-crowned Plover Vanellus albiceps In South Africa, Maclean (1993) reports White-crowned Plovers outside the KNP along the Limpopo River only (Figure 


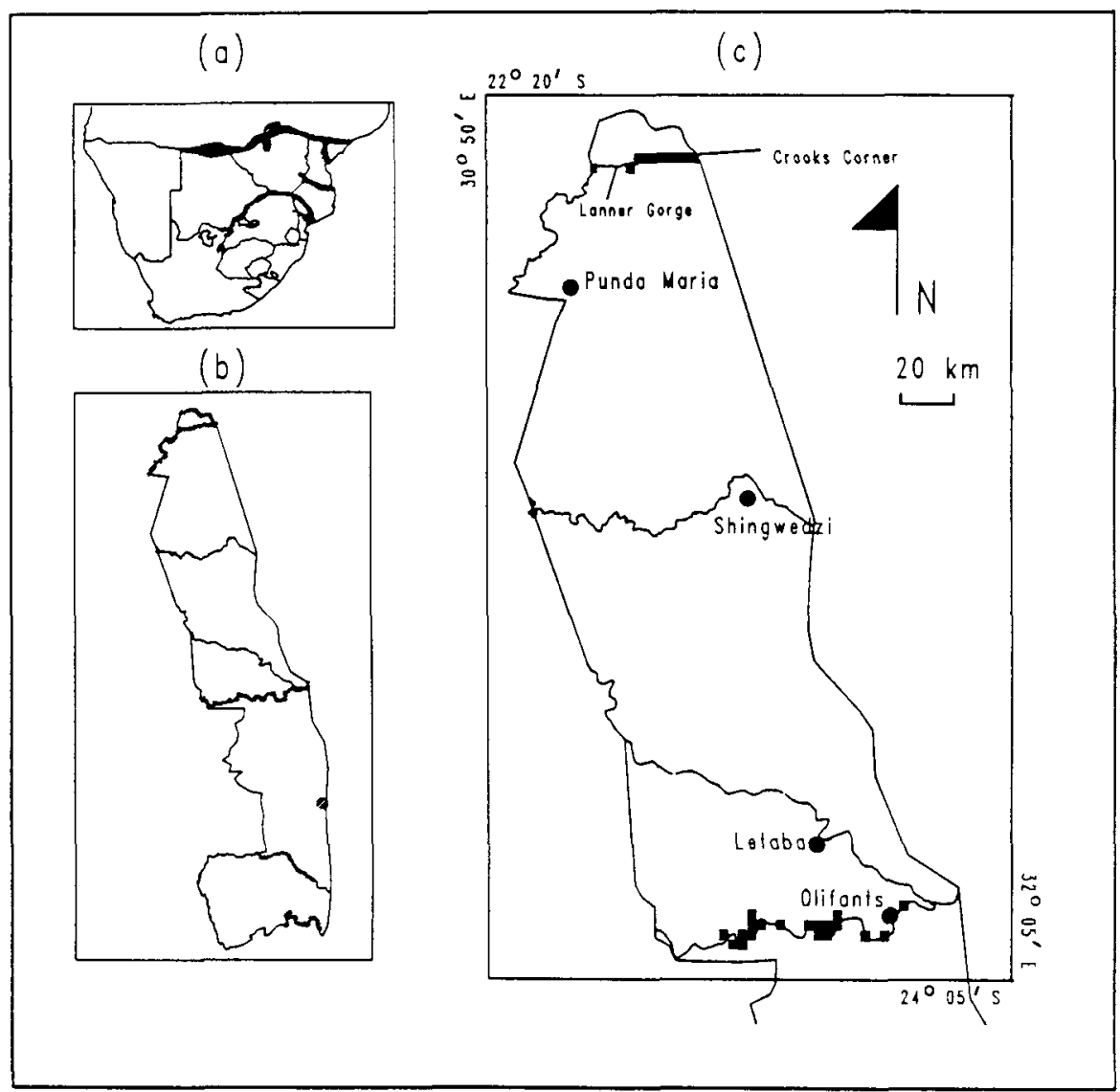

Figure 3. Distribution (shaded areas) of the White-crowned Plover (a) in southern Africa (after Maclean 1993) and (b) in the entire KNP (after Sinclair and Whyte 1991). Grid squares $(2 \times 2 \mathrm{~km})$ where this species was recorded during the study period are shown in (c).

3a). Sinclair and Whyte (1991) report a few scattered records in the southern KNP along the Sabie and Crocodile Rivers (Figure $3 b$ ), but the majority of the population is restricted to the Luvuvhu and Olifants Rivers in the northern KNP (Figures $3 \mathrm{~b}$ and $3 \mathrm{c}$ ). Each year the KNP staff conduct a helicopter survey along the major rivers specifically to count hippopotamus. Other riverine species are also counted, including the White-crowned Plover. From these surveys, it appears that $98 \%$ of the White-crowned Plover population occurs in the northern KNP (Table 3). Thus, our habitat assessments were conducted in the northern KNP only and, using the annual aerial counts, were extrapolated to include the southern KNP population.

Suitable breeding habitat for the White-crowned Plover includes river sandbanks adjoining water (Maclean 1993), which occurs along the Luvuvhu $(85.5 \mathrm{~km})$ and Olifants $(99.8 \mathrm{~km})$ Rivers in the northern KNP. Continuous stretches of suitable habitat occur along the stretch of Luvuvhu River from just before Lanner Gorge to Crook's Corner (see Figure $3 \mathrm{C}$ for locations), a length 
Table 3. White-crowned Plover counts from the annual hippopotamus survey conducted by the National Parks Board.

\begin{tabular}{|c|c|c|c|}
\hline & River system & $\begin{array}{l}\text { Mean number of } \\
\text { birds } \pm \text { standard error } \\
(n=6)\end{array}$ & Total number of birds \\
\hline Northern KNP: & $\begin{array}{l}\text { Limpopo/Luvuvhu } \\
\text { Shingwedzi } \\
\text { Letaba } \\
\text { Olifants }\end{array}$ & $\begin{array}{r}47.7 \pm 22.8 \\
0.0 \pm 0.0 \\
0.2 \pm 0.4 \\
132.7 \pm 53.0\end{array}$ & 180.6 \\
\hline Southern KNP: & $\begin{array}{l}\text { Sabie } \\
\text { Crocodile }\end{array}$ & $\begin{array}{l}2.7 \pm 1.8 \\
1.2 \pm 1.8\end{array}$ & $3 \cdot 9$ \\
\hline
\end{tabular}

Ratio northern : southern KNP $=98: 2$

The mean number of birds is a mean of survey results from 1987-1992 (i.e. $n=6$ ).

of $19 \mathrm{~km}$. During the 1991 breeding season (early summer, mainly October) this area supported 33 breeding pairs, representing a density of 1.74 pairs $/ \mathrm{km}$ of river. The remaining stretch of Luvuvhu River west of Lanner Gorge and along the western border of the KNP $(66.5 \mathrm{~km})$ is more rocky, has fewer sandbars and is less favourable. The habitat along the entire stretch of the Olifants River is most similar to the less suitable habitat of the Luvuvhu River. Nineteen less suitable stretches, totalling $70.4 \mathrm{~km}$, along the entire length of the Olifants River surveyed in March 1992 supported 100 birds ( 1.42 birds $/ \mathrm{km}$ of river). By extrapolation, the less suitable Olifants and Luvuvhu River habitat can be calculated to support 142 and 94 birds respectively. Thus, the population of White-crowned Plover in the northern KNP is approximately $66+142+94=$ 302 birds (Table 4).

To obtain an index with which to calibrate future fixed-distance strip-transects, densities per transect (Table 2) were pooled. Mean density per transect and standard error were calculated as $1.65 \pm 0.06$ pairs $/ \mathrm{km}$ in suitable habitat $(n=3)$ and $1.53 \pm 0.33 \mathrm{birds} / \mathrm{km}$ in less suitable habitat $(n=19)$, which are similar to the respective densities estimated using the spot-mapping method. White-crowned Plovers are fairly conspicuous birds and, therefore, densities estimated using the fixed-distance strip-transect method do not need to be calibrated, and a margin of error can be calculated for the estimate.

Extrapolating our results to the southern KNP (using the ratio calculated in Table 3) yields a total KNP population of White-crowned Plovers of approximately 308 birds. The annual aerial hippopotamus counts for White-crowned Plover in the northern KNP (Table 3) are lower than our river walk counts (Table 4), although still within the same order of magnitude. This was expected, since our walks concentrate solely on White-crowned Plover, which are also easier to spot on the ground.

Arnot's Chat Thamnolaea arnoti In South Africa, Maclean (1993) reports Arnot's Chat outside the KNP in the extreme north-eastern Transvaal (Figure 4a). Within the KNP, this species occurs mainly in the north (Figure $4 \mathrm{~b}$ ), and species-habitat surveys record them wherever areas of tall mopane forest with a closed understorey exist. Thus, the \% mopane tree cover in combination with the $\%$ bush cover were considered important habitat parameters for Arnot's 


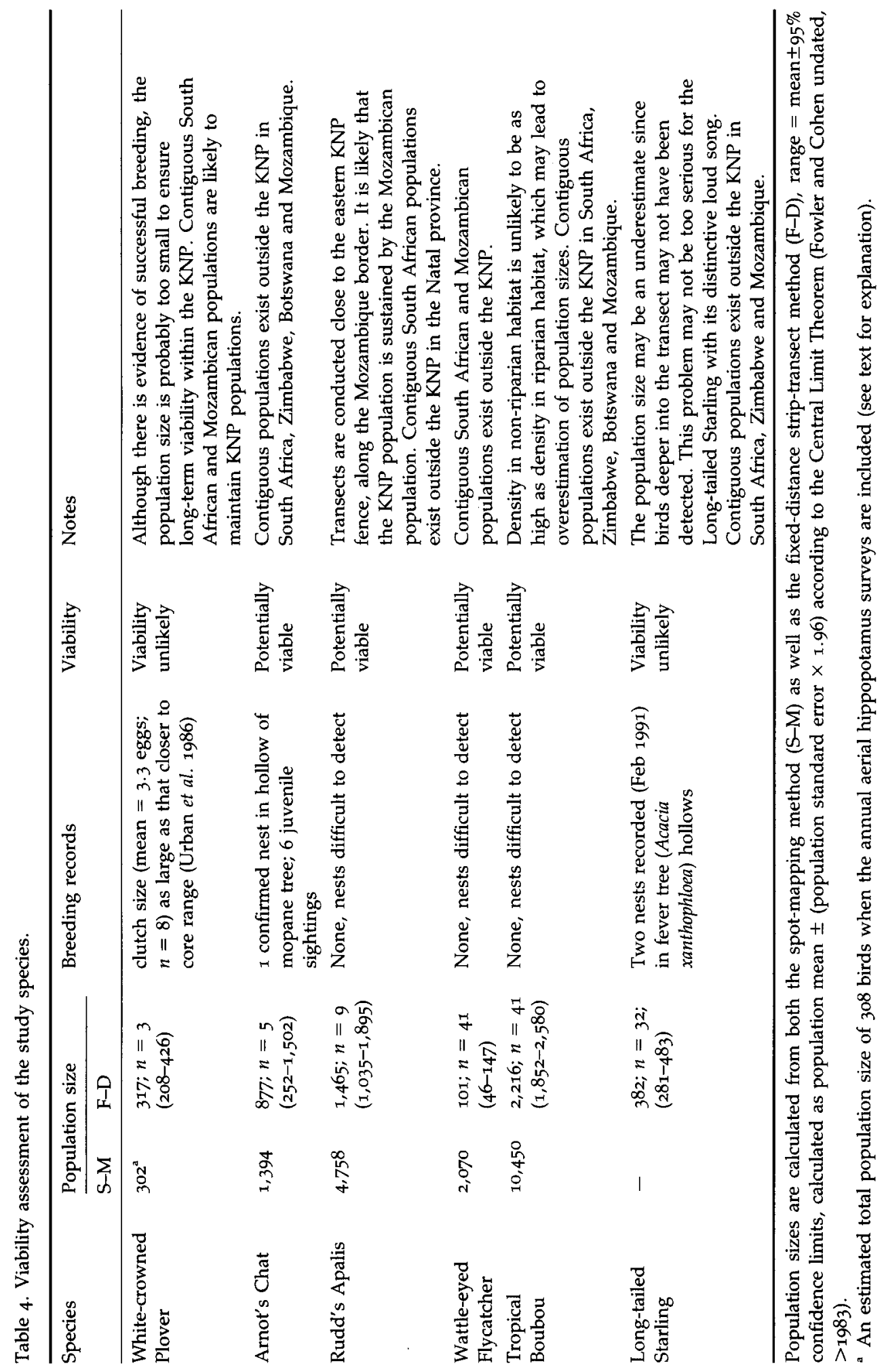




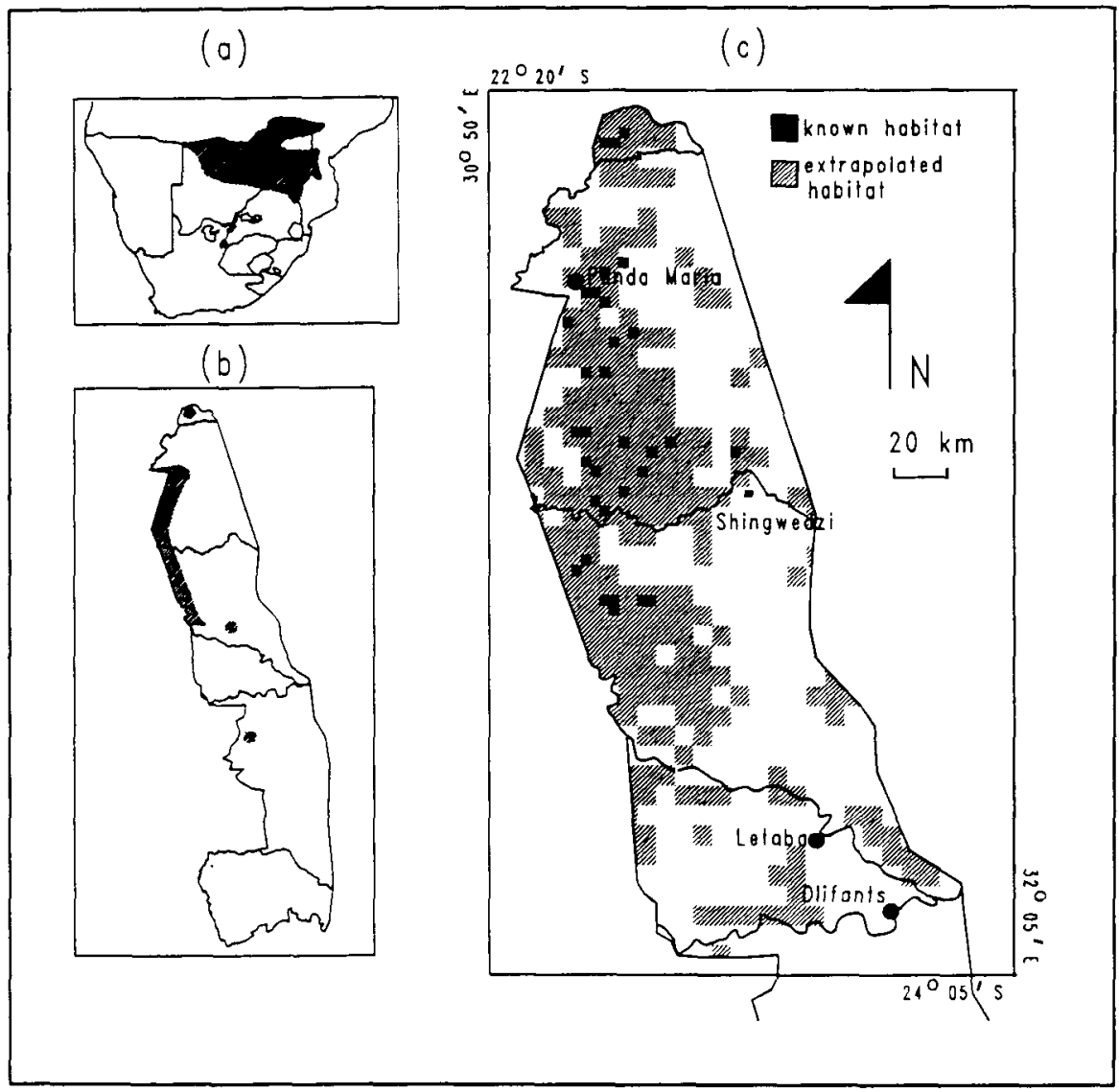

Figure 4. Distribution of Arnot's Chat (a) in southern Africa (after Maclean 1993) and (b) in the entire KNP (after Sinclair and Whyte 1991). Grid squares $(2 \times 2 \mathrm{~km})$ where this species was recorded during the study period (known habitat) and distribution of suitable habitat (extrapolated habitat) are shown in (c).

Chat. Birds were recorded only in grid squares where \% mopane tree cover $\geqslant 10 \%$ and $\%$ bush cover $\geqslant 25 \%$, a total area of $498 \mathrm{~km}^{2}$ (Figure $4 \mathrm{c}$ ).

Spot-mapping of the transect data during the breeding season (Table 2) found a total of 7 pairs in an area of $5.0 \mathrm{~km}^{2}$, yielding a density estimate of 2.80 birds/ $\mathrm{km}^{2}$. Extrapolating this density estimate to all suitable habitat, a total population size of 1,394 birds within the KNP is obtained (Table 4).

To obtain an index with which to calibrate future fixed-distance strip-transects, densities per transect (Table 2) were pooled and mean density and standard error were calculated ( $1.76 \pm 0.64$ birds $\left./ \mathrm{km}^{2} ; n=5\right)$. Extrapolating this density estimate to suitable habitat yields a population size that is $63 \%$ of the population size obtained using the spot-mapping method (Table 4).

Rudd's Apalis Apalis ruddi In South Africa, Maclean (1993) records this species in northern Natal (Figure 5a). Our study found this species to be extremely localized within the KNP (Figure $5 b$ ) and, according to the species-habitat surveys, restricted to dense, tangled thickets in the Nwambiya Sandveld area 


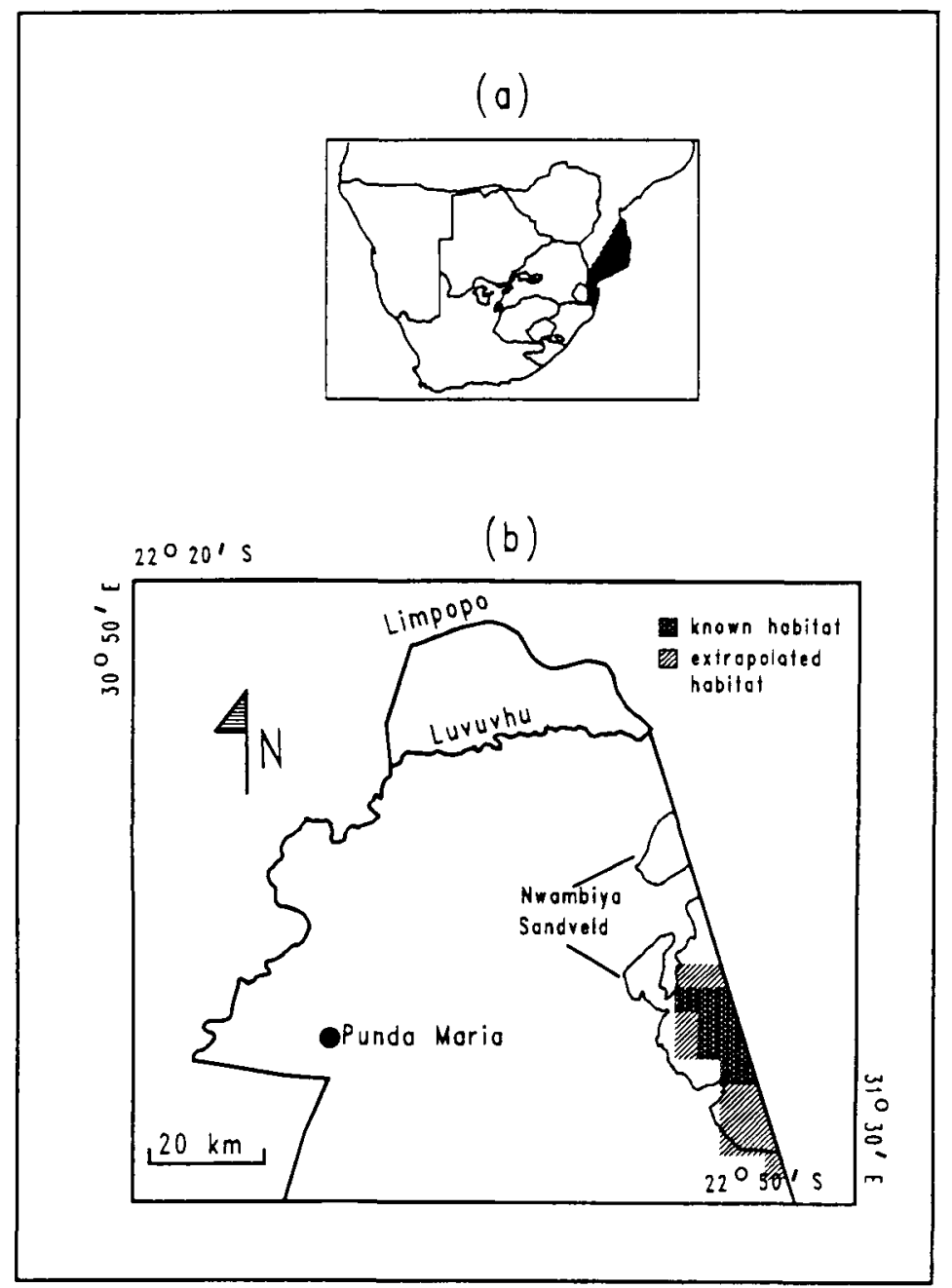

Figure 5. Distribution of Rudd's Apalis (a) in southern Africa (after Maclean 1993). Grid squares $(2 \times 2 \mathrm{~km})$ where this species was recorded during the study period (known habitat) and distribution of suitable habitat (extrapolated habitat) are shown in (b). Sinclair and Whyte (1991) do not record Rudd's Apalis in the KNP.

(see Figure 1 for location). Rudd's Apalis was recorded only in grid squares with more than $60 \%$ bush cover. Thus, all grid squares in the Nwambiya Sandveld region with $\%$ bush $\geqslant 60 \%$ were considered suitable for Rudd's Apalis, a total area of $97 \mathrm{~km}^{2}$ (Figure $5 \mathrm{~b}$ ).

Spot-mapping of the data collected on transects during the breeding season (Table 2) found a total of 52 birds (assuming that each "cluster" represents a pair of birds) in an area of $1.06 \mathrm{~km}^{2}$, yielding a density estimate of $49.06 \mathrm{birds} /$ $\mathrm{km}^{2}$. Extrapolating this density estimate to all suitable habitat, a total population size of 4,758 birds within the KNP is obtained (Table 4).

To obtain an index with which to calibrate future fixed-distance strip-transects, densities per transect (Table 2) were pooled and mean density and standard error were calculated (15.10 $\pm 2.26 \mathrm{birds} / \mathrm{km}^{2} ; n=9$ ). 


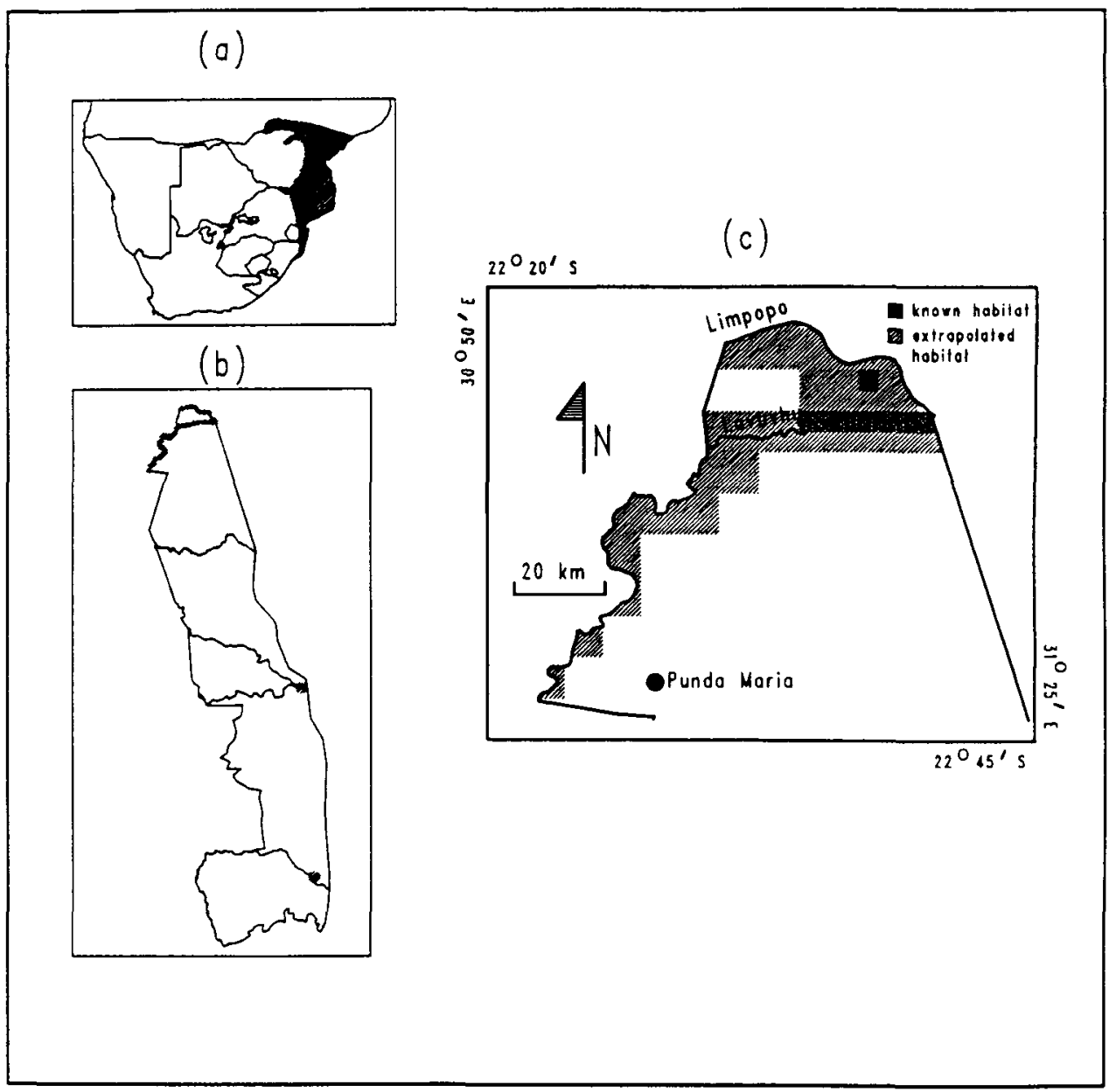

Figure 6. Distribution of Wattle-eyed Flycatcher (a) in southern Africa (after Maclean 1993) and (b) in the entire KNP (after Sinclair and Whyte 1991). Grid squares $(2 \times 2 \mathrm{~km})$ where this species was recorded during the study period (known habitat) and distribution of suitable habitat (extrapolated habitat) are shown in (c).

Extrapolating to suitable habitat yields a population size that is only $31 \%$ of the population size obtained using the spot-mapping method (Table 4).

Wattle-eyed Flycatcher Platysteira peltata In South Africa, Maclean (1993) records this species outside the KNP in both the north-eastern Transvaal and in the Natal province (Figure 6a). Sinclair and Whyte (1991) report a few scattered records on the Olifants and Sabie Rivers (Figure 6b), but the main population occurs in the northern KNP in dense riverine thickets along the Limpopo and Luvuvhu Rivers (Figure $6 b, c$ ). The area of suitable habitat along these rivers represents an area of $46 \mathrm{~km}^{2}$ (Figure $6 \mathrm{c}$ ).

Spot-mapping of the transect data (Table 2) yielded a total of 18 territories along the area of Luvuvhu River surveyed $\left(0.8 \mathrm{~km}^{2}\right)$. Each territory was assumed 
to represent a breeding pair; therefore, a total of 36 birds occurred within the area surveyed and density was calculated as $45.00 \mathrm{birds} / \mathrm{km}^{2}$. Extrapolating to all suitable habitat gives a maximum population size of 2,070 birds within the KNP (Table 4).

To obtain an index with which to calibrate future fixed-distance strip-transects, densities per transect (Table 2) were pooled and mean density and standard error were calculated $\left(2.21 \pm 0.61 \mathrm{birds} / \mathrm{km}^{2} ; n=41\right)$. Extrapolating to suitable habitat yields a population size that is only $5 \%$ of the population size obtained using the spot-mapping method (Table 4). Since the Wattle-eyed Flycatcher is difficult to detect in its dense bush habitat, it is unlikely that all individuals within the area are detected per transect. Future fixed-distance strip-transects should take this into account.

Tropical Boubou Laniarius aethiopicus In South Africa, Maclean (1993) reports this species outside the KNP along the Limpopo River (Figure $7 \mathrm{a}$ ). Within the $\mathrm{KNP}$, this species is restricted to the north (Figure $7 \mathrm{~b}$ ) and occurs most often in the riparian forests of the Limpopo/Luvuvhu valley (Sinclair and Whyte 1991), but species-habitat surveys also report it in any dense thickets of bush and trees north of Punda Maria (Figure $7 \mathrm{c}$ ). Its southernmost boundary in the KNP is Punda Maria, and all suitable habitat north of this boundary, except for habitat in the Nwambiya Sandveld area (see Figure 1 for location), was assumed to be occupied. Grid squares north of the southern boundary where the combined percentage of tree and bush cover $(T+B)$ is more than $65 \%\left(258 \mathrm{~km}^{2}\right)$ were regarded as suitable habitat (Figure $7 \mathrm{C}$ ), as well as any grid squares with riparian vegetation $\left(46 \mathrm{~km}^{2}\right)$. Censusing of this species was confined to riparian habitat and the density thus obtained was assumed to be the same in non-riparian habitat. However, density within the riparian habitat is likely to be higher than in the non-riparian habitat, so that the estimated population size may be an overestimate.

Spot-mapping of transect data yielded a total of 55 territories along the area of Luvuvhu River surveyed $\left(3.2 \mathrm{~km}^{2}\right)$. Each territory was assumed to represent a breeding pair, hence a total of 110 birds occur within the area surveyed and density was calculated as 34.38 birds $/ \mathrm{km}^{2}$. Extrapolating this density to the area occupied by riparian vegetation $\left(46 \mathrm{~km}^{2}\right)$ gives a riparian population size of 1,581 birds. Assuming the same density of Tropical Boubous in thickets away from rivers (i.e. where $\mathrm{T}+\mathrm{B}>65 \%$ ), the non-riparian population size is estimated to be 8,869 birds. Total population size is, thus, estimated to be approximately 10,450 birds (Table 4 ).

Extrapolating the mean density per transect and standard error $\left(7.29 \pm 0.61\right.$ birds $\left./ \mathrm{km}^{2} ; n=40\right)$ to suitable habitat yields a population size that is only $21 \%$ of the population size obtained using the spot-mapping method (Table 4).

Long-tailed Starling Lamprotornis mevesii In South Africa, Maclean (1993) reports this species outside the KNP along the Limpopo River (Figure 8a). Within the KNP, Long-tailed Starlings occur only in the Limpopo/Luvuvhu valley (Figure $8 \mathrm{~b}$ ). Sightings further south require confirmation (Tarboton et al. 1987) since this bird is often confused with Burchell's Starling L. australis. 


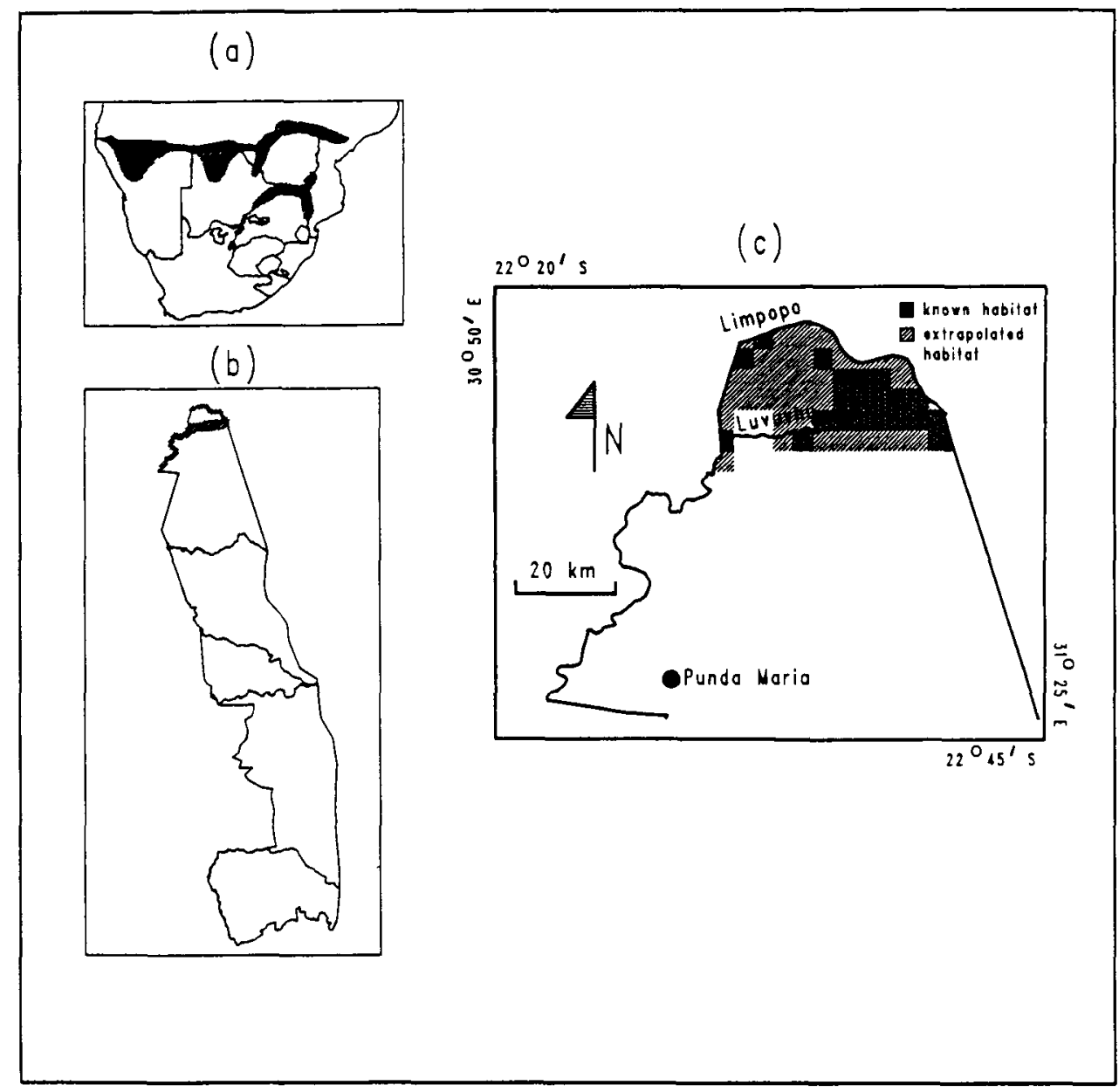

Figure 7. Distribution of Tropical Boubou (a) in southern Africa (after Maclean 1993) and (b) in the entire KNP (after Sinclair and Whyte 1991). Grid squares $(2 \times 2 \mathrm{~km})$ where this species was recorded during the study period (known habitat) and distribution of suitable habitat (extrapolated habitat) are shown in (c).

Long-tailed Starlings favour open woodland with bare ground (where they forage for fruit and insects) and tree-hollows for breeding (Maclean 1993). Thus, extent of bare ground and of \% tree cover were considered important habitat parameters for Long-tailed Starlings, which occur only where bare ground > $50 \%$ and $\%$ tree cover $>10 \%$. Using these search criteria all grid squares with habitat suitable for Long-tailed Starlings were located (Figure 8c). The areas of trees within these grid squares represent a total area of $61 \mathrm{~km}^{2}$.

Densities obtained for both transects (Table 2) were compared and were not significantly different (Mann-Whitney U-test). Thus, the data were pooled and mean density and standard error were calculated as $6.26 \pm 0.84 \mathrm{birds} / \mathrm{km}^{2}$. Extrapolating this to the area of suitable habitat $\left(61 \mathrm{~km}^{2}\right)$ yields a total population size of 382 birds in the KNP (lower and upper $95 \%$ confidence limits are 281 and 483 respectively). 
populations are treated as isolated from contiguous unprotected populations outside the park. Currently, it is likely that many KNP populations are maintained by these contiguous unprotected populations. In the event of these contiguous unprotected populations persisting, a KNP population of less than 1,000 adults may even be viable.

\section{Discussion}

Management options

Conservation priorities at regional, national and global levels differ, and management options will depend critically on the scale and goals of the conservation effort (Peterson et al. 1993). Management options discussed below therefore consider conservation of the study species at a regional level (within the KNP) as well as conservation at a national and global level.

\section{Conservation in the KNP}

According to this study, Arnot's Chat, Rudd's Apalis, Wattle-eyed Flycatcher and Tropical Boubou have population sizes large enough to be potentially viable within the KNP. However, the KNP populations of White-crowned Plover and Long-tailed Starling are probably too small to be viable in the long term. Management of all these study species should be viewed at a national level, since many populations that are deemed not viable within the KNP may be viable when other populations within South Africa are taken into account.

For conservation of these species, it is better to concentrate management efforts on bird habitats, rather than on the protection of specific species. The density data and bird-habitat association data collected in this study may serve as baseline material for future monitoring of populations in the KNP. When the areas of suitable habitat identified for each species are combined, it is apparent that the Luvuvhu/Limpopo as well as the Olifants River systems are particularly important for a number of species. The White-crowned Plover, Tropical Boubou and Wattle-eyed Flycatcher assessed in this study are all associated with such riparian habitat. Furthermore, the habitat in the Punda/Pafuri region is of prime importance to Arnot's Chat, Tropical Boubou and Long-tailed Starling.

\section{Conservation at a national level}

The conservation of the study species in South Africa should be seen in the light of metapopulation conservation (Hanski 1991), particularly given that birds are generally vagile creatures, able to move between populations more easily than many other vertebrates. Movement between populations is likely to play an important role in population dynamics and lowers the risk of extinction. The White-crowned Plover and Long-tailed Starling may not be viable within the KNP. However, these species have contiguous populations outside the KNP, extending into the Natal and/or Transvaal provinces (Figures $3 a$ and $8 \mathrm{a}$, respectively). Thus, the KNP populations may be important to the overall 
viability within South Africa even though they themselves do not represent viable populations.

\section{Conservation at a global level}

Rare species are often threatened with extinction, thus conservation priority is often given to rare species. The species of this study are listed as "rare" in the South African Red Data Book (Brooke 1984) simply because their ranges just extend into South Africa from further north where they are more widespread (Hall and Moreau 1970, Snow 1978). At a global scale, it therefore seems less important to assign conservation priority to these species purely because of a political boundary. From a global viewpoint, the White-crowned Plover, Arnot's Chat, Tropical Boubou and Long-tailed Starling (Figures 3a, 4a, 7a and 8a, respectively) also gain protection in Botswana and Zimbabwe, closer to the centre of their ranges. Considering that the level of conservation in Botswana and Zimbabwe is comparable to the level in South Africa, these species are relatively well protected. However, Rudd's Apalis and the Wattle-eyed Flycatcher should receive higher global conservation priority, since their ranges within southern Africa are mainly confined to Mozambique (Figures $5 \mathrm{a}$ and 6a, respectively) where civil war and political instability has led to the breakdown of protection measures within the country's national parks and reserves (Stuart and Adams 1990).

\section{Conclusions}

The results of this study should be viewed within the limits of several factors. These include problems related to habitat scale and problems inherent to censusing cryptic species. Furthermore, given that the KNP ranges for the study species were based on recorded sightings, and thus represent minimum geographic ranges, the population sizes may be underestimated. Moreover, the severe drought in the KNP during the survey may have led to further underestimation of population sizes particularly for the White-crowned Plover, which requires stretches of sandbars next to water for breeding. Nevertheless, the results give conservative estimates of population sizes which can be used as management guidelines and as a baseline against which future population trends can be monitored. However, prior to monitoring, the accuracy of the technique used to predict suitable habitat should be tested. This can be done by visiting grid squares predicted to have suitable habitat for a species and confirming the presence of that species. Thereafter, randomized fixed-distance strip-transects within areas of suitable habitat can be conducted, using the calibration factor calculated from the spot-mapping method in this study.

The KNP, with its high degree of habitat management and protection, has the potential of making a significant contribution toward the conservation of the study species, particularly those that are likely to be viable within the park. Populations not considered viable within the KNP should not be disregarded because, combined with contiguous populations outside the park, they may be viable at a national and global level. 


\section{Acknowledgements}

We thank the Foundation for Research Development, Department of Environmental Affairs, The Southern Life Association and Pretoria Software Solutions for financial support. The help and guidance of Prof. P. V. August is greatly appreciated. Thanks to the KNP staff, especially Dr H. Biggs and Dr P. Viljoen, for supplying digitized maps of their roads, rivers and landscape types as well as results of their annual aerial surveys. Finally, we wish to thank $\mathrm{Dr}$ P. Ryan for commenting on the manuscript, as well as Ms C. Zank, Mr M. Kriek, Mr K. Begg and Mr P. Chadwick for helping to collect the data.

\section{References}

Bibby, C. J., Burgess, N. D. and Hill, D. (1992) Bird census techniques. London: Academic Press.

Brooke, R. K. (1984) South African Red Data Book - birds. Pretoria: Foundation for Research and Development (South African National Scientific Programmes Report No. 97).

Edwards, D. K., Dorsey, G. L. and Crawford, J. A. (1981) A comparison of three avian census methods. Pp.170-176 in C. J. Ralph and J. M. Scott, eds. Estimating numbers of terrestrial birds. Lawrence, Kansas: Allen Press Inc.

Fowler, J. and Cohen, L. (undated) Statistics for ornithologists. London: British Trust for Ornithology (Publ. No. 22).

Franzreb, K. E. (1981) A comparative analysis of territorial mapping and variable-strip transect censusing methods. Pp.164-169 in C. J. Ralph and J. M. Scott, eds. Estimating numbers of terrestrial birds. Lawrence, Kansas: Allen Press Inc.

Gertenbach, W. P. D. (1980) Rainfall patterns in the Kruger National Park. Koedoe 23: 35-43.

Hall, B. P. and Moreau, R. E. (1970) An atlas of speciation in African passerine birds. London: Trustees of the British Museum.

Hanski, I. (1991) Single-species metapopulation dynamics: concepts, models and observations. Pp.17-38 in M. Gilpin and I. Hanski, eds. Metapopulation dynamics: empirical and theoretical investigations. London: Academic Press.

Kemp, A. C. (1980) The importance of the Kruger National Park for bird conservation in the Republic of South Africa. Koedoe 23: 99-122.

Maclean, G. L. (1993) Roberts' birds of southern Africa. Cape Town, South Africa: CTP Book Printers.

Peterson, A. T., Flores-Villela, O. A., León-Paniagua, L. S., Llorente-Bousquets, J. E., Luis-Martinez, M. A., Navarro-Sigüenza, A. G., Torres-Chávez, M. G. and Vargas-Fernández, I. (1993) Conservation priorities in Mexico: moving up in the world. Biodiversity Lett. 1: $33-38$.

Pulliam, H. R. (1988) Sources, sinks and population regulation. Amer. Nat. 132: 652-661.

Sinclair, I. and Whyte, I. J. (1991) Field guide to the birds of the Kruger National Park. Cape Town, South Africa: Struik Publishers.

Snow, D. W. (1978) An atlas of speciation in African non-passerine birds. London: Trustees of the British Museum.

Stevens, G. (1992) Spilling over the competitive limits to species coexistence. Pp.40-58 in N. Eldredge, ed. Systematics, ecology, and the biodiversity crisis. New York: Columbia University Press.

Stoms, D. M. (1992) Effects of habitat map generalization in biodiversity assessment. Photogrammetric Engineering and Remote Sensing 58: 1587-1591.

Stoms, D. M. (1994) Scale dependence of species richness maps. Professional Geographer 46: $346-358$. 
Stuart, S. and Adams, R. (1990) Biodiversity in Subsaharan Africa and its islands: conservation management and sustainable use. Oxford, U.K: Information Press (Occ. Pap. IUCN Species Survival Commission no. 6).

Tarboton, W. R., Kemp, M. I. and Kemp, A. C. (1987) Birds of the Transvaal. Pretoria, South Africa: Gutenberg Book Printers.

Thomas, C. D. (1990) What do real population dynamics tell us about minimum viable population sizes? Conserv. Biol. 4: 324-327.

Turner, M. G., O'Neill, R. O., Gardner, R. H. and Milne, B. T. (1989) Effects of changing spatial scale on the analysis of landscape pattern. Landscape Ecology 3: 153-162.

Urban, E. K., Fry, C. H., and Keith, S. (1986) The birds of Africa, 2. London: Academic Press.

Verner, J. (1985) Assessment of counting techniques. Current Orn. 2: 247-302.

J. L. HURFORD, A. T. LOMBARD and G. A. BENN

Percy FitzPatrick Institute of African Ornithology, University of Cape Town, Rondebosch, 7700, South Africa

A. C. KEMP

Transvaal Museum, P.O. Box 413, Pretoria, ooo1, South Africa 